\title{
Oestrogen Receptors and Oestrogen-Induced Protein Synthesis in the Uterus of Diabetic Rats
}

\author{
E. Ekka, I. Vanderheyden, and R. De Hertogh \\ Endocrinology and Nutrition Unit, University of Louvain, Brussels, Belgium
}

\begin{abstract}
Summary. The present study was undertaken to examine whether the diabetic state influenced the early stages of oestrogen action in the uterus. Ovariectomized streptozotocin diabetic rats were given intravenous infusions of oestradiol-17 B one day to 4-7 months after the initiation of diabetes. Oestradiol was taken up to a similar extent (on a wet weight basis) by the uteri of diabetic and control animals. Oestradiol receptor levels were similar in the cytosol of control and diabetic rats $(1.06 \pm 0.19$ and $1.01 \pm 0.27 \mathrm{pmol} /$ uterus respectively). Nuclear translocation of the receptor complex under the influence of oestradiol infusion occurred similarly in both groups. The stimulation of a specific oestrogeninduced protein in the uteri occurred at a similar rate in both groups from one day to 4-7 months after the onset of diabetes. Thus streptozotocin diabetes of short to long duration does not interfere with the early stages of oestrogen action.
\end{abstract}

Key words: Diabetes in rats, streptozotocin, oestrogen, oestradiol-17 B receptors, uterus, protein synthesis, subcellular binding.

The influence of diabetes in pregnancy has been the subject of many investigations dealing mostly with the deleterious effect of disturbed maternal environment on fetal growth and development [1]. However, the effect of the diabetic state on the functioning of the hormonally dependent uterus itself has not often been considered. Kirkland et al [2] described a relative inhibition of oestrogen-induced uterine cell division in alloxan-induced diabetic rats. Insulin was able to restore a normal mitotic index. Foglia et al. $[3,4]$ previously described a reduction in the normal response of the uterus to oestrogen administration in subtotally pancreatectomized rats. Zilberstein [5] and Fowler et al. [6] also described a decreased activity of oestrogens on the uterus of diabetic animals. Lostroh $[7,8]$ showed increased protein synthesis in cultures of mouse uteri under the influence of insulin, while an insulin induced increase in the "ion pump" in the uterus has also been described [9]. Finally, Miura and Koide [10] reported a mutual potentiating effect of insulin and oestrogens on the incorporation of uridine into uterine RNA of insulin-treated diabetic rats.

One of the earliest actions of the oestrogens on their target tissues is to bind to a specific receptor in the cytosol and migrate in the form of steroid-receptor-complexes to the nucleus where a stimulatory effect is exerted at the genomic level $[11,12]$. The present study was undertaken to examine the early steps of oestrogen action in the uterus of the diabetic rats, receptor binding and stimulation of early protein synthesis.

\section{Materials and Methods}

\section{Animals}

Female Wistar rats were bilaterally ovariectomized at 2 months and rendered diabetic by the IV injection of streptozotocin (Upjohn Research Laboratories, Kalamazoo, Mich.) $(65 \mathrm{mg} / \mathrm{kg}$ in $0.05 \mathrm{~mol} / 1$ citrate and $0.154 \mathrm{~mol} / 1$ saline, $\mathrm{pH} 4.8$ ) after $16 \mathrm{~h}$ fasting. Food and water were then allowed ad libitum to avoid hypoglycaemia. Blood glucose levels were determined with a Reflomat (Boehringer, Mannheim). Ketonuria was measured with Acetest tablets (Ames).

Table 1 shows the prompt rise in blood glucose level, followed by the decrease at $12 \mathrm{~h}$ and the secondary and sustained rise by $16 \mathrm{~h}$ [13]. All animals had moderate or heavy ketonuria after 3 month of diabetes. In long-term diabetic rats (more than 3 months) the insulin content of the pancreas [13] (kindly determined for us with anti-rat insulin antibody by J. C. Henquin, Diabetes Unit, University of Louvain, Brussels) had fallen to less than $12 \%$ of the controls ( $16 \pm 2$ vs $136 \pm 12 \mathrm{ng} / \mathrm{mg}$ respectively $(\mathrm{n}=5))$. 
Table 1. Blood glucose levels (Mean \pm SD) and ketonuria (Acetest) after injection of streptozotocin $(65 \mathrm{mg} / \mathrm{kg}$ ) to $2 \mathrm{month}$ old ovariectomized rats

\begin{tabular}{|c|c|c|c|c|c|c|c|c|c|c|c|}
\hline & \multicolumn{11}{|c|}{ Time after streptozotocin } \\
\hline & \multicolumn{8}{|l|}{ Hours } & \multicolumn{2}{|c|}{ Weeks } & \multirow{2}{*}{$\frac{\text { Months }}{3 \text { to } 7}$} \\
\hline & 0 & 2 & 5 & 12 & 16 & 24 & 48 & 96 & 1 & 6 & \\
\hline $\mathrm{n}$ & 73 & 2 & 9 & 9 & 3 & 33 & 17 & 27 & 5 & 14 & 47 \\
\hline $\begin{array}{l}\text { Blood glucose } \\
(\mathrm{mg} / 100 \mathrm{ml})\end{array}$ & $94 \pm 12$ & 310 & $212 \pm 47$ & $123 \pm 33$ & $>350$ & $>350$ & $>350$ & $>350$ & $>350$ & $>350$ & $>350$ \\
\hline $\begin{array}{l}\text { Ketonuria } \\
\text { (n) }\end{array}$ & 0 & 0 & 0 & 0 & 0 & 0 & 3 & 9 & 0 & 4 & 47 \\
\hline
\end{tabular}

$\mathrm{n}=$ number of animals. From $16 \mathrm{~h}$ all blood glucose determinations (Reflomat) exceeded $350 \mathrm{mg} / 100 \mathrm{ml}$

\section{Analytical Techniques}

Uteri were fractionated as previously described $[14,15]$. The homogenizing buffer (TEM), $\mathrm{pH} 7.4$, contained $10 \mathrm{mmol} / 1$ Tris, $1.5 \mathrm{mmol} / 1 \mathrm{EDTA}$ and $14 \mathrm{mmol} / 1$ mercaptoethanol. The oestradiol-17 B receptor level was measured in the cytosol and nuclear pellet with an exchange method according to Katzenellenbogen et al [17] and Anderson et al. [16]. A detailed methodology of receptor binding will be described elsewhere (to be published). Briefly, after uterine homogeneization, high speed cytosol (1 uterus equivalent $/ \mathrm{ml}$ ) was obtained and stripped of unbound oestradiol with charcoal-dextran. After addition of oestradiol- ${ }^{3} \mathrm{H}$ $(6 \mathrm{nmol} / 1)$ or oestradiol- ${ }^{3} \mathrm{H}(6 \mathrm{nmol} / \mathrm{l})+$ oestradiol $(24 \mathrm{nmol} / 1)$ to paired aliquots, cytosol was incubated for $60 \mathrm{~min}$ at $4{ }^{\circ} \mathrm{C}$ followed by $18 \mathrm{~h}$ at $20^{\circ} \mathrm{C}$. After cooling, free ligand was precipitated by charcoal-dextran and the specific binding calculated from the total minus the non-specifically bound radioactivity. The low speed nuclear pellet, washed three times with TEM buffer, was resuspended in the same buffer $(0.5$ uterus $/ \mathrm{ml})$ and gently rehomogenized. Exchange was conducted on paired aliquots as described for cytosol, at $37^{\circ} \mathrm{C}$ for $1 \mathrm{~h}$. After cooling, nuclei were precipitated and washed three times with TEM buffer. Bound radioactivity was then extracted with ethanol and specific binding was calculated as for cytosol. All receptor measurements were made in triplicates in both cytosol and nuclear pellet which agreed to within 10 to $15 \%$ between the extremes.

The receptor binding capacity can be expressed as pmol/uterus or pmol/mg DNA. Both expressions gave similar results, there being no significant difference in DNA content per uterus between the control and the diabetic rats. Uterine wet weights were also similar in both groups. Hence only the pmol/uterus will be used here.

The stimulation of the specific oestrogen induced protein synthesis [18] was determined by the in vitro incorporation of ${ }^{3}-\mathrm{H}-$ or ${ }^{14} \mathrm{C}$-leucine by uteri of stimulated and unstimulated animals respectively. The method of quantitative measurement of induced protein synthesis, using cellogel strip electrophoresis of cytosol proteins, has been described previously [19]. Results were expressed as percent increase of the ${ }^{3} \mathrm{H} /{ }^{14} \mathrm{C}$ ratio in the induced protein area above the mean ${ }^{3} \mathrm{H} /{ }^{14} \mathrm{C}$ ratio outside this area.

Sedimention characteristics of cytosolic and nuclear oestradiol receptor complexes have been studied by ultracentrifugation on a sucrose density gradient $(5-20 \%)$ as previously described [14].

The IV infusion of oestradiol-2, 4, 6, 7- ${ }^{3} \mathrm{H}(160 \mathrm{Ci} / \mathrm{mmol})$ (New England Nuclear) and the measurement of uptake of radioactivity in the uterus were performed as described earlier. Results were expressed as mean $\pm \mathrm{SD}$. Statistical significance between groups was determined with the " $t$ " test of Student.

\section{Results}

\section{Uptake of Oestradiol ${ }^{3} \mathrm{H}$ by the Uterus}

Oestradiol- ${ }^{3} \mathrm{H}$ was infused IV in control and diabetic rats at varying time intervals after streptozotocin administration. The rate of infusion $(96 \mu \mathrm{g} / \mathrm{h}$ for $8 \mathrm{~min}$ followed by $1.5 \mu \mathrm{g} / \mathrm{h}$ for $82 \mathrm{~min}$ ) was chosen to attain rapid saturation of the receptors and maximum stimulation of induced protein synthesis $[19,21]$. At the end of the infusion time, the animals were decapitated and the uteri were rapidly removed, cleaned, weighed and homogenized in acetone to extract all the radioactive products accumulated in the tissue [20]. The latter consisted mainly of unconjugated oestradiol- ${ }^{3} \mathrm{H}$ itself (more than $80 \%$ ) [20, 22]. Hence the results shown on Table 2 are expressed in ng equivalents of oestradiol- ${ }^{3} \mathrm{H}$ per gram of wet tissue. As shown in Table 2, the uptake of oestradiol ${ }^{3} \mathrm{H}$ was similar in control and diabetic rats, at early times as well as $\mathbf{4 2}$ days after streptozotocin injection.

\section{Sedimentation Profile of Oestradiol ${ }^{3} \mathrm{H}$ Bound to Uterine Subcellular Fractions}

Oestradiol $-{ }^{3} \mathrm{H}$ was infused intravenously at a rate of $180 \mathrm{ng} / \mathrm{h}$ for $4 \mathrm{~h}$ in three control and three diabetic rats, three days after streptozotocin injection. At the end of the infusion time, the three uteri of each group were homogenized together in Tris-EDTA sucrose buffer as described earlier [14]. The high speed cytosol as well as the $\mathrm{KCl}(0.4 \mathrm{~mol} / \mathrm{l})$ soluble extract from nuclear pellet were prepared. Both fractions were layered on a $5-20 \%$ sucrose gradient containing $\mathrm{KCl}(0.4 \mathrm{~mol} / \mathrm{l})$ and centrifuged at $105000 \times g$ for $16 \mathrm{~h}$.

Figure 1 shows the migration profiles of the subcellular associated radioactivity in controls and diabetics. The $4 \mathrm{~S}$ peak characterizing the cytosolic receptor was present in both groups as well as the $5 \mathrm{~S}$ 
Table 2. Uterine concentration of radioactive oestrogens. Total radioactive products (see text) were measured in rat uterus after IV infusion of oestradiol ${ }^{3} \mathrm{H}$ for $90 \mathrm{~min}$ and expressed in ng equivalents of oestradiol $-{ }^{3} \mathrm{H}$, per $\mathrm{g}$ of wet tissue

\begin{tabular}{lll}
\hline $\begin{array}{l}\text { Duration of } \\
\text { diabetes (days) }\end{array}$ & Controls & Diabetics \\
\hline 1 to 3 & $17.8 \pm 2.4$ & $15.8 \pm 2.4$ \\
& $(12)$ & $(12)$ \\
7 & $16.9 \pm 0.5$ & $19.7 \pm 3.1$ \\
& $(6)$ & $(6)$ \\
22 & $18.3 \pm 10.9$ & $18.3 \pm 3.6$ \\
& $(5)$ & $(6)$ \\
42 & $19.2 \pm 3.5$ & $17.9 \pm 1.8$ \\
& $(6)$ & $(6)$ \\
\hline
\end{tabular}

Mean \pm SD. Number of animals in parentheses
Table 3. Oestradiol receptor levels. Measurements were made in uterine fractions of control and long-term ( 4 to 7 months) diabetic rats before and after the IV administration of oestradiol-17 B (see text)

\begin{tabular}{llllll}
\hline & \multicolumn{2}{l}{$\begin{array}{l}\text { Cytosol receptors } \\
\text { pmol/uterus }\end{array}$} & & \multicolumn{2}{l}{$\begin{array}{l}\text { Nucleus receptors } \\
\text { pmol/uterus }\end{array}$} \\
\cline { 2 - 3 } \cline { 5 - 6 } $\begin{array}{l}\text { Time after } \\
\text { oestradiol } \\
\text { (min) }\end{array}$ & Diabetic & Control & & Diabetic & Control \\
\hline 0 & & & & & \\
\hline 90 & $1.01 \pm 0.27$ & $1.06 \pm 0.19$ & & $0.09 \pm 0.06$ & $0.07 \pm 0.04$ \\
& $(11)$ & $(10)$ & & $(11)$ & $(10)$ \\
& $0.16 \pm 0.03$ & $0.16 \pm 0.08$ & & $0.72 \pm 0.20$ & $0.67 \pm 0.13$ \\
$(6)$ & $(7)$ & $(6)$ & $(8)$ \\
\hline
\end{tabular}

Mean \pm SD. Number of animals in parentheses

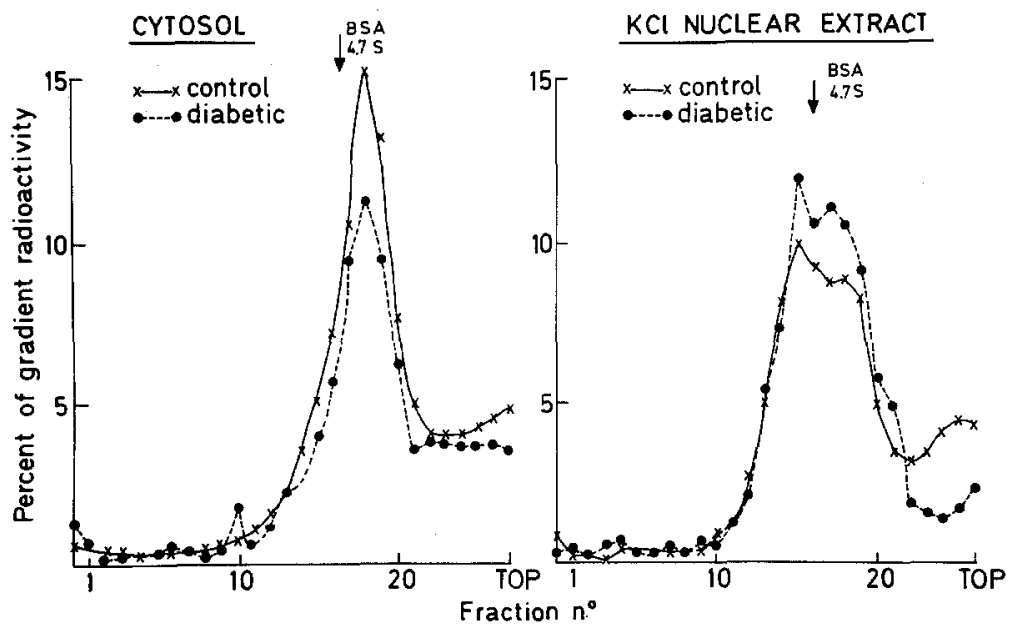

Fig. 1. Sedimentation profile on sucrose gradient (sucrose $5-20 \%, \mathrm{KCl} 0.4 \mathrm{~mol} / \mathrm{l}$ ) of cytosol and $\mathrm{KCl}$ soluble nuclear extract (see Methods) of pooled uteri from control and diabetic rats at the end of a 4 hour IV infusion of oestradiol- ${ }^{3} \mathrm{H}$. In this experiment, the rate of infusion was $180 \mathrm{ng} / \mathrm{h}$. BSA (bovine serum albumin) had on this gradient, a sedimentation coefficient of $4.7 \mathrm{~S}$

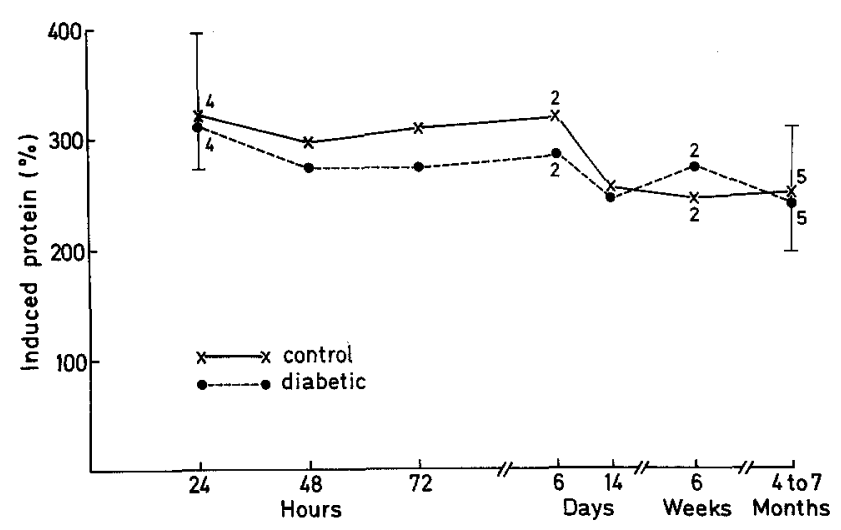

Fig. 2. Relative induced protein synthesis stimulation in percent of basal level (see Methods) in uteri from control and diabetic rats at the end of a $90 \mathrm{~min}$ infusion of oestradiol $17 \beta(96 \mu \mathrm{g} / \mathrm{h}$ for $8 \mathrm{~min}$ $+1.5 \mu \mathrm{g} / \mathrm{h}$ for $82 \mathrm{~min}$ ). Number of experiments and standard deviations are indicated on the graph. Time elapsed from induction of diabetes is shown on the abscissa peak characterizing the specific nuclear receptor [14]. Similar profiles were repeatedly obtained in both short-term and long-term diabetic rats (4-7 months). As expected, the migration profiles of cytosol on sucrose gradients without $\mathrm{KCl}$ showed $8 \mathrm{~S}$ peaks and heavy aggregates (not shown).

\section{Receptor Levels and Kinetics in the Uterus}

Table 3 shows the levels of cytosolic and nuclear receptors before and 90 minutes after the intravenous infusion of oestradiol- $17 \beta$ at a rate of $96 \mu \mathrm{g} / \mathrm{h}$ for $8 \mathrm{~min}$ followed by $1.5 \mu \mathrm{g} / \mathrm{h}$ for $82 \mathrm{~min}$. The receptor levels were similar in the cytosol before oestradiol infusion. The nuclear translocation occurred to approximately the same extent in both groups after oestradiol infusion. 


\section{Stimulation of Oestrogen Induced Protein Synthesis}

Figure 2 shows the stimulation of oestrogen induced protein synthesis in percent of basal level in the uterus of control and diabetic animals at varying time after the injection of streptozotocin. Oestrogen induced protein synthesis was quantified at the end of an IV infusion of oestradiol-17 $\beta$ at a rate of $96 \mu \mathrm{g} / \mathrm{h}$ for $8 \mathrm{~min}$ followed by $1.5 \mu \mathrm{g} / \mathrm{h}$ for $82 \mathrm{~min}$. No differences were observed between controls and diabetics up to 4 to 7 months after the injection of streptozotocin.

\section{Discussion}

Streptozotocin-induced diabetes produced a catabolic state characterized by high glycosuria, ketonuria and weight loss. Pain and Garlick [23] observed a depression of protein synthesis in striated and cardiac muscles but not in the liver of streptozotocin-induced diabetic rats. In the present study, we observed no decrease in the ability of intravenously infused oestradiol to stimulate the early protein synthesis in the uteri of ovariectomized diabetic rats. The capacity for stimulation of induced protein synthesis by oestradiol remained unchanged as long as 4 to 7 months after the onset of diabetes. Gala and Sanford [24] obtained a normal oestrogen induced increase of uterine weight in rats treated 8 to 10 days previously with streptozotocin. However Kirkland et al. [2] observed decreased oestrogen induced uterine cell division seven days after the onset of alloxan diabetes. The normal stimulation of induced-protein synthesis reported here must be distinguished from late effects like uterine weight increase and cell division and may not be in contradiction to Kirkland's results. Indeed, late effects necessitate a longer retention of the receptor-hormone complex in the nuclei than induced protein synthesis [25-28] (see below).

On the other hand, the route of administration of the hormone is important. In similar experiments to those reported here, except that oestradiol was injected intraperitoneally, we observed that induced protein response was significantly decreased in diabetics [29] (to be published). It should also be noted that the results observed in the uterus may not necessarily be extended to other tissues. Indeed, Gala and Sandford [24] observed a similar increase in uterine weight under the influence of oestrogens in diabetic and control rats although an increase in pituitary weight was absent in diabetics.

Induced protein synthesis is stimulated proportionately to the binding of oestradiol to the uterine receptors and more specifically to the accumulation of oestradiol-receptor complex in the uterine nuclei $[21,26]$. The persistance, in the diabetics, of a normal stimulation of induced protein synthesis by oestradiol, as reported here, suggests that the kinetics of the oestradiol receptor complex was also preserved. This was indeed the case. Uterine cytosol receptor levels were similar in long-term diabetic rats and in age matched normal rats. After the intravenous administration of oestradiol the nuclear translocation of the hormone receptor complex was similar in both groups. These results fit with previous observations by. Denari and Rosner [30] and ourselves [31] that oestradiol, whether injected [30] or infused [31] intravenously was taken up similarly in the uteri of normal or diabetic animals. Again, the route of oestradiol administration should be taken into consideration. Indeed, the retention of the receptor-complex in the nucleus was shorter after intraperitoneal injection as compared to intravenous infusion of the hormone (to be published). The binding characteristics may also be differently impaired in different tissues, as suggested by the observations of Denari and Rosner [30] who described a normal uptake of oestradiol by uteri and diminished uptake by anterior hypothalamus and anterior pituitary of diabetic animals.

In conclusion, the cellular machinery which regulates oestradiol uptake, binding and nuclear translocation, and the early events of genomic activation seems to be unimpaired in the uterus of streptozotocin-induced diabetic rats despite the presence of an important catabolic state.

Acknowledgements. This work was supported by a grant from the Fonds de la Recherche Scientifique Medicale. Strptozotocin was kindly supplied by Upjohn Laboratories (Kalamazoo, Mich.) through the courtesy of Dr. J. Decoster (Upjohn-Belgium).

\section{References}

1. Sutherland HW, Stowers JM (1979) Carbohydrate metabolism in pregnancy and the newborn. Springer, Berlin Heidelberg New York

2. Kirkland JL, Lapointe LB, Stancel GM (1979) Inhibition of estrogen induced uterine cell division in alloxan induced diabetes (Abstr), 61rst Annual Meeting of the Endocrine Society, p 214

3. Foglia VG, Borghelli RF, Chieri RA, Fernandez-Collazo EL, Spindler I, Wessely $O(1963)$ Sexual disturbances in the diabetic rat. Diabetes 12: 231-237

4. Foglia VG, Deperalta Ramos MC, Rivera Cortes LRY (1967) Fertilidad y alteraciones utero-ovaricas en la rata pancreatomizada. Rev Soc Argent Biol 43: 158-167

5. Zilberstein RM (1960) Oestrogen-insulin interaction on the uterus of the rat. Nature 186: 635-637

6. Fowler DD, Szego CM, Sloan SH (1963) Curtailment of the uterotrophic action of oestrogen by impaired histamine liberation in the alloxan-diabetic rat. Reversal by insulin and by adrenalectomy. Endocrinology 72: 626-637 
7. Lostroh $\mathrm{AJ}$ (1963) Effect of insulin and of DL-aldosterone on protein synthesis by mouse uteri in organ culture. Exp Cell Res 32: $327-332$

8. Lostroh AJ (1966) Effect of glucose pyruvate and insulin on protein synthesis in explanted mouse uteri. Am J Physiol 211: $809-814$

9. Lostroh AJ, KrahlME (1973) Accumulation in vitro of $\mathrm{Mg}$ and $\mathrm{K}$ in rat uterus: ion pump activity. Biochim Biophys Acta 291: $260-268$

10. Miura S, Koide SS (1970) Effect of insulin and growth hormone on rat uterine RNA synthesis. Proc Soc Exp Biol Med 133: 882-885

11. Clark JH, Peck EJ, Hardin JW, Erickson H (1978) The biology and pharmacology of oestrogen receptor binding: relationship to uterine growth. In: O'Malley BW, Birbaumer L (eds) Receptors and hormone action. Academic Press, New York San Francisco London, p 1-31

12. Spelsberg TC, Thrall G, Martin-Dani G, Webster RA, Boyd PA (1979) Steroid-receptor interaction with chromatin. In: Hamilton TH, Clark JH, Sadler WA (eds) Ontogeny of receptors and reproductive hormone action. Raven Press, New York $\mathrm{p}$ 31-63

13. Junol A, Lambert AE, Orci L, Pictet R, Gonet AE, Renold AE (1967) Studies of the diabetogenic action of steptozotocin. Proc Soc Exp Biol Med 126: 201-205

14. De Hertogh R, Ekka E, Vanderheyden I, Hoet JJ (1973) Subcellular distribution and binding of $6,7{ }^{3} \mathrm{H}$ oestradiol in rat uterus, at equilibrium, after long-term intravenous infusion. $J$ Steroid Biochem 4: 289-299

15. Ekka E, De Hertogh R (1976) Comparison of the binding of 2, $4,6,7{ }^{3} \mathrm{H}$ oestradiol-17 $\beta$ to the immature rat uterus under in vivo, in vitro and cell-free conditions. I Steroid Biochem 7: $241-247$

16. Anderson J, Clark JH, Peck E (1972) Oestrogen and nuclear binding sites. Determination of specific sites by ${ }^{3} \mathrm{H}$-oestradiol exchange. Biochem J 126: 561-567

17. Katzenellenbogen JA, Johnson HJ, Carlson KE (1973) Studies on the uterine cytoplasmic estrogen binding protein. Thermal stability and ligand dissociation rate. An essay of empty and filled sites by exchange. Biochemistry 12 : $4092-4099$

18. Notides A, Gorski J (1966) Oestrogen-induced synthesis of a specific uterine protein. Proc Natl Acad Sci USA 56: 230-235

19. Ekka E, Vanderheyden I, De Hertogh R (1977) Stimulation of early protein synthesis in the uterus of the ovariectomized rat by continuous infusion of ${ }^{3} \mathrm{H}$-oestradiol- $17 \beta$ in vivo. $\mathrm{I}$. relationship with infusion time and tissue concentration. J Steroid Biochem 8: 959-963

20. De Hertogh R, Ekka E, Vanderheyden I, Hoet JJ (1971) In vivo observation of reversible binding of oestradiol- $17 \beta 6,7$ ${ }^{3} \mathrm{H}$ in rat uterus. Measurement of a "biological exchange". Endocrinology 88: 165-174
21. De Hertogh R, Vanderheyden I, Ekka E (1977) Stimulation of early protein synthesis in the uterus of the ovariectomized rat, by continuous infusion of ${ }^{3} \mathrm{H}$-Oestradiol $-17 \beta$ in vivo. II Relationship with infusion rate and tissue concentration. I Steroid Biochem 8: 965-969

22. De Hertogh R, Ekka E, Vanderheyden I (1971) Equilibrium concentration of $6,7{ }^{3} \mathrm{H}$ oestrone and $6,7{ }^{3} \mathrm{H}$ oestradiol metabolites in female rat tissues during long-term intravenous infusions. Acta Endocrinol (Kbh) 66: 401-416

23. Pain VM, Garlick PJ (1974) Effect of streptozotocin diabetes and insulin treatment on rate of protein synthesis in tissues of the rat in vivo. J Biol Chem 249: 4510-4514

24. Gala RR, Sandford J (1979) The influence of oestrogen on pituitary growth and on prolactin production in vitro in diabetic rat. Proc Soc Exp Biol Med 161: 583-588

25. Anderson JN, Clark JH, Peck El (1972) The relationship between nuclear receptor-oestrogen binding and uterotrophic responses. Biochem Biophys Res Commun 48: 1460-1468

26. Ruh TS, Katzenellenbogen B, Katzenellenbogen JA, Gorski J (1973) Oestrone interaction with the rat uterus: in vitro response and nuclear uptake. Endocrinology 92: 125-134

27. Lan NC, Katzenellenbogen BS (1976) Temporal relationships between hormone receptor binding and biological responses in the uterus: studies with short and long-acting derivatives of oestriol. Endocrinology 98: 220-227

28. Clark JH, Preck EJ (1976) Nuclear retention of receptor-oestrogen complex and nuclear acceptor sites. Nature 260: $220-227$

29. De Hertogh R, Ekka E, Vanderheyden I (1979) Effect of streptozotocin induced diabetes in ovariectomized rats on oestradiol-17 $\beta\left(\mathrm{E}_{2}\right)$ binding to the uterine receptors. Correlation with the stimulation of early protein synthesis. (I. P). Acta Endocrinol [Suppl] (Kbh) 225: 269

30. Denari JH, Rosner JM (1972) Sexual steroid uptake in the alloxanized diabetic rat. Steroid Lip Res 3: 151-155

31. Ekka E, De Hertogh R, Vanderheyden I (1978) Oestradiol 2, $4,6,7{ }^{3} \mathrm{H}-17 \beta$ uptake and subcellular distribution in the uterine of ovarietomized diabetic rat; induction of ealry protein synthesis. J Steroid Biochem 9: 833

Received: 5 August 1980, and in revised form: 8 December 1980

Dr. R. De Hertogh

Endocrinology and Nutrition Unit

U. C. L. 54.29

Avenue E. Mounier 54

B-1200 Bruxelles

Belgium 